\title{
Calculated Panel Reactive Antibody Measurement
}

National Cancer Institute

\section{Source}

National Cancer Institute. Calculated Panel Reactive Antibody Measurement. NCI

Thesaurus. Code C132381.

The determination of the calculated panel reactive antibody (CPRA), which is based on the number/type of unacceptable HLA antigens to which an org an recipient has been sensitized, and which algorithmically estimates the level of sensitization in the recipient. The CPRA is computed from HLA antigen frequencies in a given donor population using both anti-HLA class I and class II antibody specificities; it also represents the percentage of actual organ donors that express one or more unacceptable HLA antigens to which a recipient may react adversely. 